\title{
Synthesis of Novel Organic Dyes Containing Coumarin Moiety for Solar Cell ${ }^{\dagger}$
}

\author{
Hyunbong Choi, Chul Baik, Hyun Jun Kim. Jeum-Jong Kim. Kihyung Song, ${ }^{+}$Sang Ook Kang, ${ }^{*}$ and Jaejung Ko \\ Department of Chemistry, Korea University, Jochiwon, Chungnam 339-700, Korea. "E-mail: jko@ikorea.ac.kr. \\ "Deparment of Chemistry, Korea National University of Education, Cheongwon, Chungbuk 363-791, Korea \\ Received Jume 14, 2007
}

\begin{abstract}
Novel organic dyes, JK-34, JK-35 and JK-36 containing bis-dimethylfluorenyl amino coumarin unit are designed and synthesized. Nanocrystalline $\mathrm{TiO}_{2}$ dye-sensitized solar cells were fabricated using these dyes. Under standard global AM 1.5 solar condition, the JK-34 sensitized cell gave a short circuit photocurrent density of $10.05 \mathrm{~mA} \mathrm{~cm}^{-2}$, open circuit voltage of $0.65 \mathrm{~V}$, and a fill tactor of 0.68 , corresponding to an overall conversion efficiency $\eta$ of $4.54 \%$. We found that the power conversion efficiency was shown to be quite sensitive to the structural modifications of bridging thiophene moiety.
\end{abstract}

Key Words : Fluorenyl, Coumarin, Organic dyes, Solar cell

\section{Introduction}

Increasing energy demands and concems over global warming have led to a greater focus on renewable energy sources in recent years.' The conversion of solar energy to electricity appears as one of the technologies that can replace fossil fuels. Dye-sensitized solar cells (DSSCs) based on mesoporous nanocrystalline $\mathrm{TiO}_{2}$ films have attracted significant attention as low-cost devices and can reach light to high electric power conversion efficiencies of $8-11 \%{ }^{2}$ In these cells, the sensitizer is one of the key elements for high power conversion efficiency. Some polypyridyl ruthenium (II) complexes ${ }^{3}$ have been used as efficient sensitizers because they have an intense metal-to-ligand charge transfer transition in the visible region. Although the ruthenium complexed dyes exhibited high efficiency and long-tem stability, ${ }^{+}$they contain a limited precious metal and they are hard to purify. Recently, impressive photovoltaic performance has been obtained with some organic coumarin," indoline, ${ }^{6}$ oligoene, ${ }^{7}$ merocyanine, ${ }^{8}$ and hemicyanine ${ }^{9}$ dyes having efficiencies in the range of 5-9\%. Very recently, we reported highly efficient and stable organic dyes containing bis-dimethylfluorenyl amino donor unit. ${ }^{10}$ The bis-dimethylfluorenyl moiety was introduced to prevent aggregation via molecular stacking by the bulky nonplanar structure and to ensure greater resistance to degradation when explosed to light and high-temperature. A major factor responsible for the high photoconversion efficiency of an organic dyesensitized solar cell can be tuned by the structural modification. ${ }^{11}$ In our previous works, we adapted the $(9,9-$ dimethylfluoren-2-yl)amino phenyl, ${ }^{10}$ benzo $[b]$ furan, ${ }^{12}$ benzo[b]thiophene $\mathrm{e}^{13}$ and $\mathrm{N}$-ary] carbazole moiety ${ }^{14}$ as the donor moiety. Another promising design strategy is replacement of the above moieties with the coumarin electron donor. Changing the electron donor would affect the highest occupied molecular orbital and lowest unoccupied molecular orbital levels of the dye and consequently, the absorption properties.

In this article, we report three new organic dyes containing [bis (9,9-dimethy]fluoren-2-y])amino]coumarin as electron donor and cyano acrylic acid as electron acceptor bridged by thiophene unit or vinylene thiophene unit (Figure I).

\section{Results and Discussion}

The novel organic dyes $\mathbf{J K}-\mathbf{3 4} \sim \mathbf{3 6}$ were prepared by the stepwise synthetic protocol illustrated in Scheme 1. The reaction started with 7-amino-3-bromo-4-methylcoumarin.

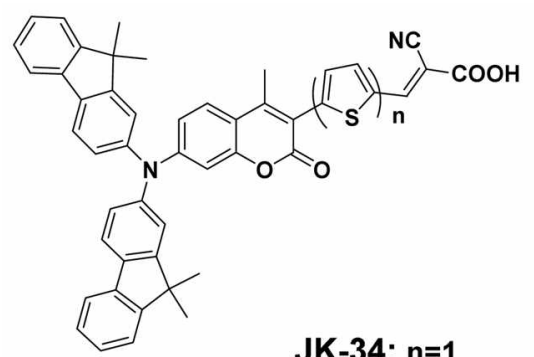

JK-34: $n=1$

JK-35: $n=2$

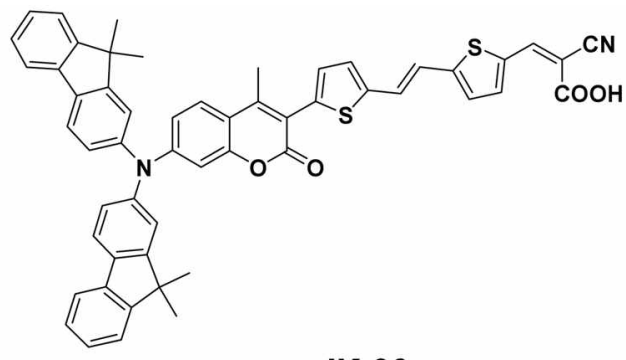

JK-36

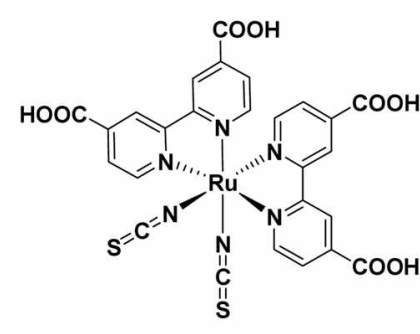

N3

Figure 1. Structure of JK-34, JK-35, JK-36 and N3. 

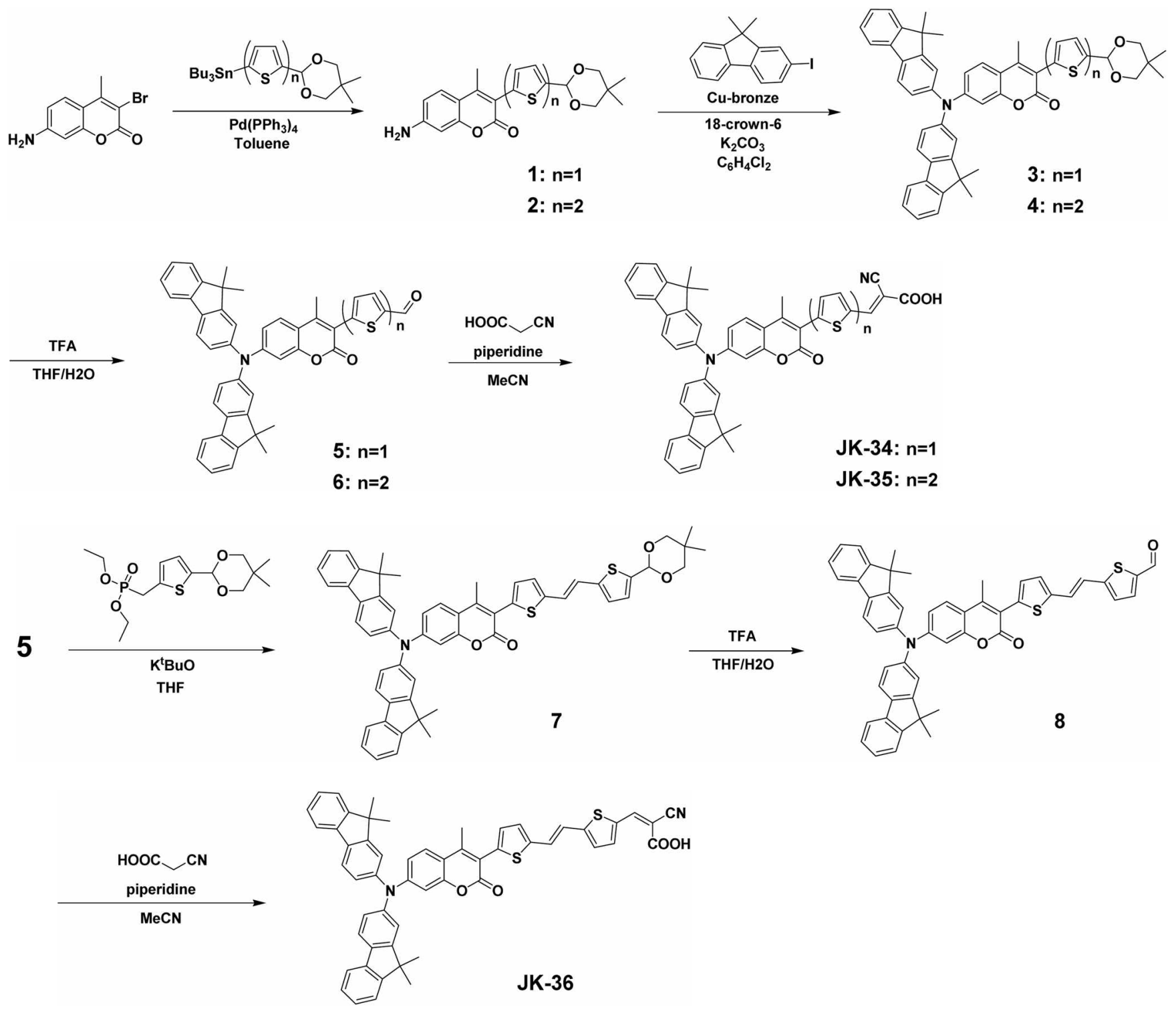

Scheme 1. Schematic Diagram for the Synthesis of Organic Dyes JK-34, JK-35, JK-36.

The coumarin mono- and bithiophenes 1 and 2 were synthesized by coupling reaction of 7-amino-3-bromo-4-methylcoumarin with stannylthiophene units in the presence of a catalytic amount of tetrakis(triphenylphosphine)palladium(0) according to the Stille reaction conditions. ${ }^{15}$ Fluorene substituted coumarin derivatives 3 and $\mathbf{4}$ were obtained by Ullmann coupling reaction. ${ }^{16}$ These thiophene derivatives were converted into their corresponding thiophene aldehydes 5 and $\mathbf{6}$ by dedioxanylation with trifluoroacetic acid (TFA). An acetonitrile solution of thiophene aldehyde derivatives ( 5 and 6) and cyanoacetic acid were refluxed in the presence of piperidine for $8 \mathrm{~h}$. Solvent removal followed by purification using chromatography yielded $\mathbf{J K}-\mathbf{3 4}$ and $\mathbf{J K}-35$. We have also designed to insert the ethylene unit between two thiophenes in order to lengthen the $\pi$-conjugation. Introduction of ethylene unit augmented the absorption extinction coefficient and red-shifted the absorption peaks. Coupling reaction of aldehyde 5 with diethyl(5-(5,5-dimethyl-1,3- dioxan-2-y])thiophen-2-y])methylphosphonate under HornerEmmons-Wittig coupling ${ }^{17}$ condition using potassium tertbutoxide in THF led to 7 . This was then converted to the aldehyde 8 , which yielded the dye JK-36 on treatment of cyanoacetic acid.

For the fabrication of DSSC, three sensitizers have been used to manufacture solar cell devices to explore currentvoltage characteristics using $12+4 \mu \mathrm{m} \mathrm{TiO} \mathrm{T}_{2}$ transparent layers. The first $\mathrm{TiO}_{2}$ layer of $12 \mathrm{am}$ thickness was prepared by screen printing $\mathrm{TiO}_{2}$ paste (Solaronix, $13 \mathrm{~nm}$ paste), and the second $\mathrm{TiO}_{2}$ scattering layer of $4 \mathrm{\mu m}$ thickness was coated with a different paste (CCIC, HWP-400) for the photo-scattering. The double layer film was treated with 40 $\mathrm{mM} \mathrm{TiCl}_{4}$ solution. The resulting layer was dried at $500^{\circ} \mathrm{C}$ for $30 \mathrm{~min}$. After cooling to $100^{\circ} \mathrm{C}$, the films were immersed into the JK-34, JK-35, and JK-36 solution $(0.3 \mathrm{mM}$ dyes in ethanol containing $10 \mathrm{mM}$ of chenodeoxycholic acid). The stained $\mathrm{TiO}_{2}$ electrode and $\mathrm{Pt}$-counter electrode 


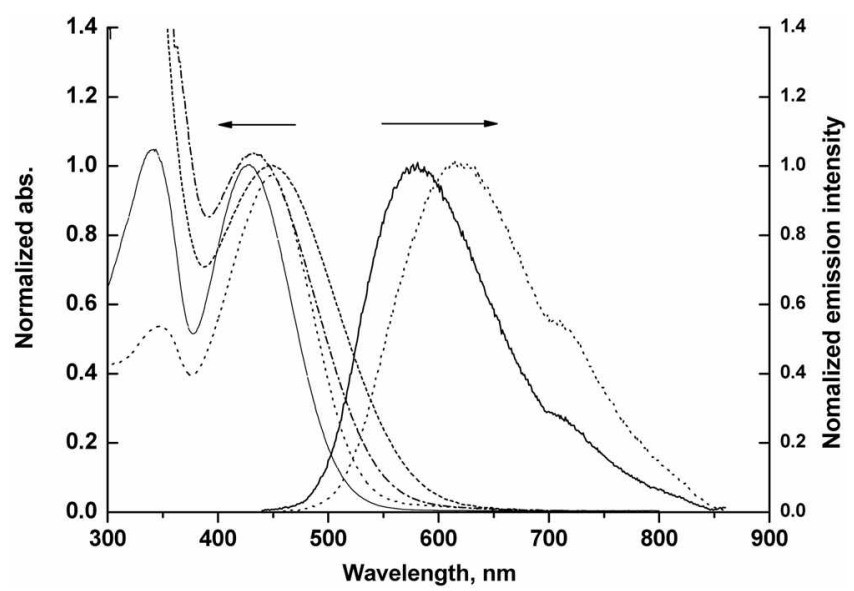

Figure 2. Absorption and emission spectra of JK-34 (solid line) and JK-36 (dot line) in ethanol and absorption spectra of JK-34 (dashed dot line) and JK-36 (short dashed line) absorbed on $\mathrm{TiO}_{2}$ film. The emission spectra were obtained using the sanc solution by exciting at $429 \mathrm{~nm}$ for $\mathbf{J K}-34$ and $450 \mathrm{~nm}$ for $\mathbf{J K}-36$ at $298 \mathrm{~K}$.

were assembled into a sealed sandwich cell by heating with a hot-melt film (Surlyn 1702, $25 \mu \mathrm{m}$ thickness) as a spacer between the electrodes. The electrolyte was composed of 0.6 M 3-hexyl-1,2-dimethyl imidazolium iodide, $0.04 \mathrm{M} \mathrm{Is}$ $0.025 \mathrm{M} \mathrm{LiI}, 0.05 \mathrm{M}$ guanidium thiocyanate and $0.28 \mathrm{M}$ tertbutylpyridine in acetonitrile.

The UV-vis and emission spectra of JK-34 and JK-36 in ethanol are shown in Figure 2 and listed Table 1, together with the UV-vis spectra of the corresponding dyes absorbed on $\mathrm{TiO}_{2}$ film. The absorption spectra of the JK-34 and JK35 display visible band at $429 \mathrm{~nm}$ and $431 \mathrm{~nm}$, respectively, which is due to the $\pi-\pi$ transition of the conjugated molecule. A slight red-shifted band at about $2 \mathrm{~nm}$ and a large extinction coefficient of $\mathbf{J K}-\mathbf{3 5}$ compared to those of $\mathbf{J K}-\mathbf{3 4}$ are due to the increase of the $\pi$-conjugation system by thiophene unit. The introduction of ethylene unit in JK-36 also induced the red-shifted band at about $20 \mathrm{~nm}$ compared to JK-34 and JK-35. The absorption spectra of all the dyes JK-34 JK-36 on $\mathrm{TiO}_{2}$ film are broadened due to the interaction of the anchoring group with the organic dyes in $\mathrm{TiO}_{2}$ electrodes. Such broadening of the absorption spectrum is desirable for harvesting the solar spectrum and leads to a large photocurrent. The dyes on $\mathrm{TiO}_{2}$ film have red-shifted bands via $J$-aggregation. We also observed that the dyes JK34 JK-36 exhibited strong luminescence maxima of 578 -
$643 \mathrm{~nm}$ when they are excited within their $\pi-\pi^{3}$ bands in an air-equilibrated solution at $298 \mathrm{~K}$.

Electrochemical properties of the dyes JK-34 JK-36 were evaluated by cyclovoltametry in acetonitile with $0.1 \mathrm{M}$ tetrabutyl ammonium hexafluorophosphate using $\mathrm{TiO}_{2}$ film with adsorbed dyes as working electrode. The results are listed in Table 1. The three organic dyes absorbed on $\mathrm{TiO}_{2}$ film showed quasi-reversible behaviors. The oxidation potentials of three organic dyes were measured to be 1.37 $1.39 \mathrm{~V} v s$. NHE, an oxidation potential energetically favorable for iodide oxidation. The reduction potentials of three dyes calculated from the oxidation potentials and the $E_{0-0}$ determined from the intersection of absorption and emission spectra is listed in Table 1. The excited state oxidation potentials $\left(E_{\mathrm{OX}}^{\prime}\right)$ of the dyes (JK-34: $-1.09 \mathrm{~V}$ vs. NHE; JK-35: $-1.03 \mathrm{~V}$ vs. NHE; JK-36: $-0.98 \mathrm{~V}$ vs. NHE) are much negative than the conduction band of $\mathrm{TiO}_{2}$ at approximately $-0.5 \mathrm{~V} v \mathrm{NHE}$.

(a)

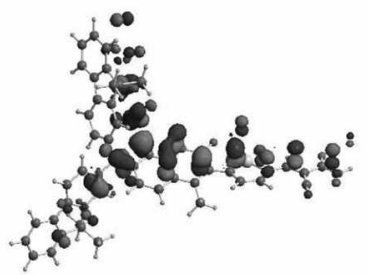

$\mathrm{HOMO}$

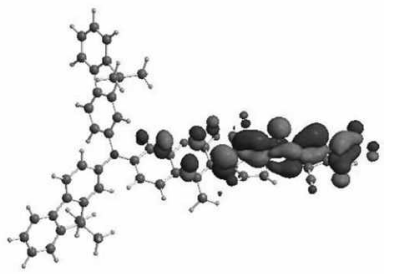

LUMO (b)
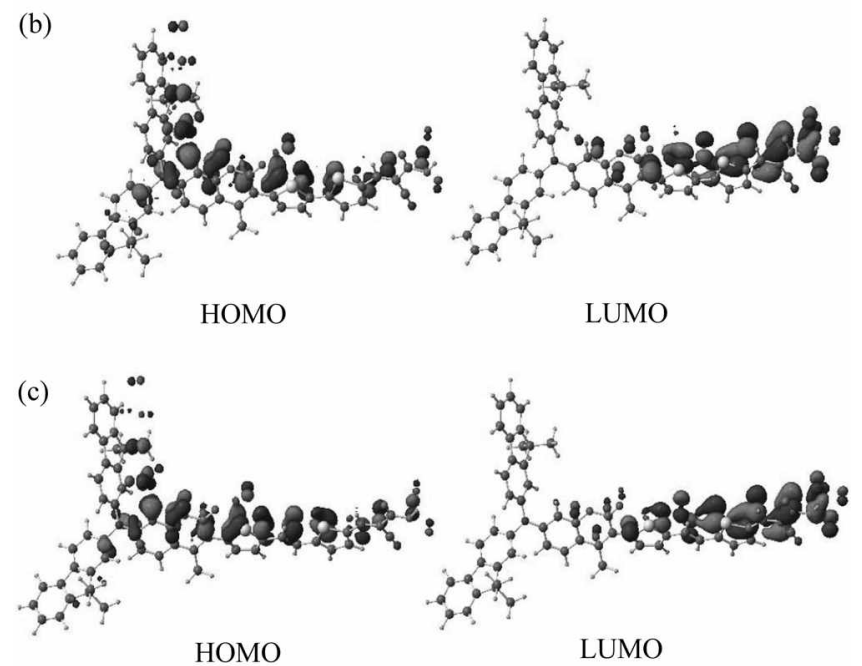

Figure 3. Isodensity surface plots of the HOMO and LUMO of (a) JK-34, (b) JK-35, and (c) JK-36.

Table 1. Optical, redox and DSSC performance parameters of dyes

\begin{tabular}{|c|c|c|c|c|c|c|c|c|}
\hline Dye & $\lambda_{12} \operatorname{lom}\left(6 \pi \mathrm{M}^{-1} \mathrm{sm}^{-1}\right)$ & $E_{0 \mathrm{x}}^{b} / \mathrm{V}$ & $E_{0-0} / \mathrm{N}$ & $E_{\text {LUMNO }} / \mathrm{V}$ & $J_{\mathrm{si}}\left(\mathrm{mAcm}^{-2}\right)$ & $V_{o c}(\mathrm{~V})$ & $\mathrm{FF}$ & $\eta t^{\prime}(\%)$ \\
\hline JK-34 & $429(22900)$ & 1.38 & 2.47 & -1.09 & 10.05 & 0.65 & 0.68 & 4.54 \\
\hline JK-35 & $431(39000)$ & 1.37 & 2.40 & -1.03 & 9.44 & 0.65 & 0.70 & 4.34 \\
\hline JK-36 & $450(25000)$ & 1.39 & 2.37 & -0.98 & 9.87 & 0.64 & 0.69 & 4.41 \\
\hline N3 & & & & & 13.13 & 0.73 & 0.66 & 6.32 \\
\hline
\end{tabular}

Absorption spectra were measured in ethanol solution. ${ }^{t} \mathrm{Oxidation} \mathrm{potential} \mathrm{of} \mathrm{dyes} \mathrm{on} \mathrm{T}_{1} \mathrm{O}_{2}$ were measured in $\mathrm{CH}_{3} \mathrm{CN}$ with $0.1 \mathrm{M}\left(n-\mathrm{C}_{4} \mathrm{H}_{0}\right)_{4} \mathrm{NPF}_{6}$ with

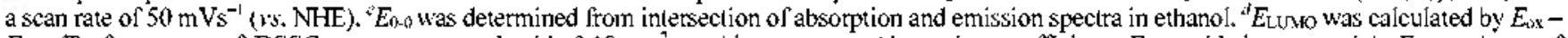
$E_{0,0}$ 'Perfomances of DSSCS were measured with $0.18 \mathrm{~cm}^{2}$ working area. $\varepsilon$ : Absorption coefficient; $E_{0 \mathrm{~d}}$ : oxidation potential; $E_{0,0}$ : voltage of intersection point between absorption and emission spectra; $J_{s s}:$ short-circuit photocurrent density; $V_{0:}:$ open-circuit photovoltage; $\Gamma T:$ fill factor; $y t$ total power conversion efliciency. 


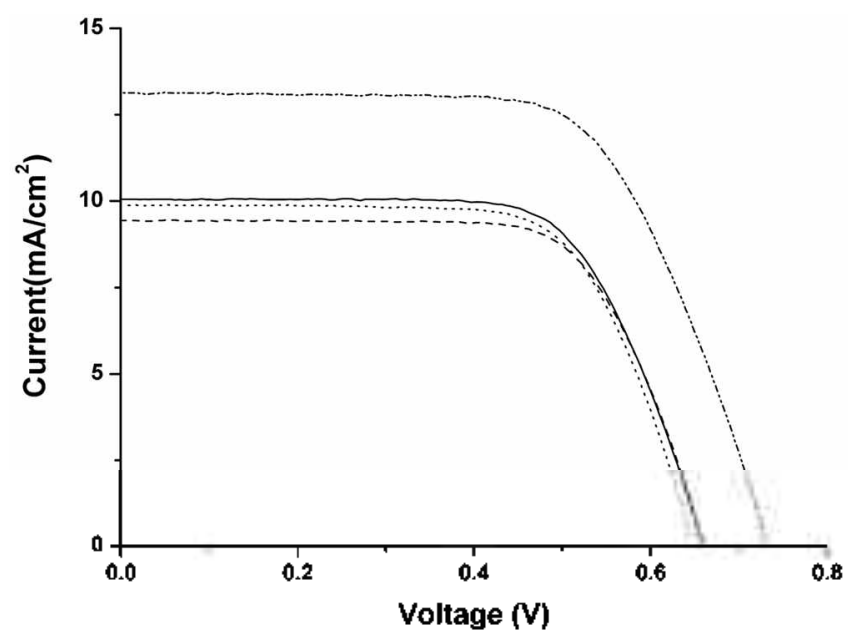

Figure 4. $\Lambda$ photocurrent voltage curve obtained with a DSSC based JK-34 (solid line), JK-35 (dashed line), JK-36 (dot line) and N3 (dashed dot-dot line) under AM 1.5 radiation $\left(100 \mathrm{mWcm}^{-2}\right)$.

To gain insight into the geometrical configuration and photophysical properties, molecular orbital calculations of the three sensitizers were performed with the TD-DFT on B3LYP/3-21G* (Figure 3). The calculation illustrates that the HOMO of JK-34 and JK-35 is delocalized over the $\pi$ conjugated system through the phenyl amino group and the LUMO is delocalized over the cyanoacrylic unit through thiophene. On the other hand, the HOMO of JK-36 is heavily delocalized over the conduit channel from pheny] amino unit to thiophene group. Examination of the HOMO and LUMO of these dyes indicates that HOMO-LUMO excitation move the electron distribution from the pheny] amino unit to the cyanoacrylic acid moiety and the photoinduced electron transfer from the dyes to $\mathrm{TiO}_{2}$ electrode can be efficiently occurred by the HOMO-LUMO transition.

The J-V curve for the DSSCs based on JK-34 and JK-35 is presented and compared with N3 dye in Figure 4. Under standard global AM 1.5 solar condition, the JK-34, JK-35 and JK-36 sensitized cell gave the short circuit photocurrent density $\left(J_{\mathrm{sc}}\right)$ of $10.95,9.44$ and $9.87 \mathrm{~mA} \mathrm{~cm}$, open circuit voltage $\left(V_{c}\right)$ of $0.65,0.65$ and $0.64 \mathrm{~V}$ and a fill factor of $0.68,0.70$ and 0.69 , corresponding to an overall conversion efficiency $\eta$ of $4.54,4.34$ and $4.44 \%$, respectively. Under the same condition, the $\mathbf{N 3}$ sensitized cell gave a $J_{s c}$ of 13.13 $\mathrm{mA} \mathrm{cm}{ }^{-2}, V_{\mathrm{ec}}$ of $0.73 \mathrm{~V}$ and a fill factor of 0.66 , corresponding to $\eta$ of $6.32 \%$. From these results, we have observed that the solar energy-to-electricity efficiency of JK-34 was slightly higher than that of JK-36 even though JK-36 has a high molar extinction coefficiency and redshifted compared to those of JK-34. In this stage, we can not explain this photophysical property clearly. However, it was well observed that because the more conjugated organic dyes with a vinyl unit are more flexible on $\mathrm{TiO}_{2}$ surface than that of rigid conjugated dyes, the flexible conjugated organic dyes can lie on the neighboring $\mathrm{TiO}_{2}$ surface and can affect the electronic state of the conduction potential of $\mathrm{TiO}_{2}$, and this effect can reduce the electron injection efficiency from dye to $\mathrm{TiO}_{2}$.

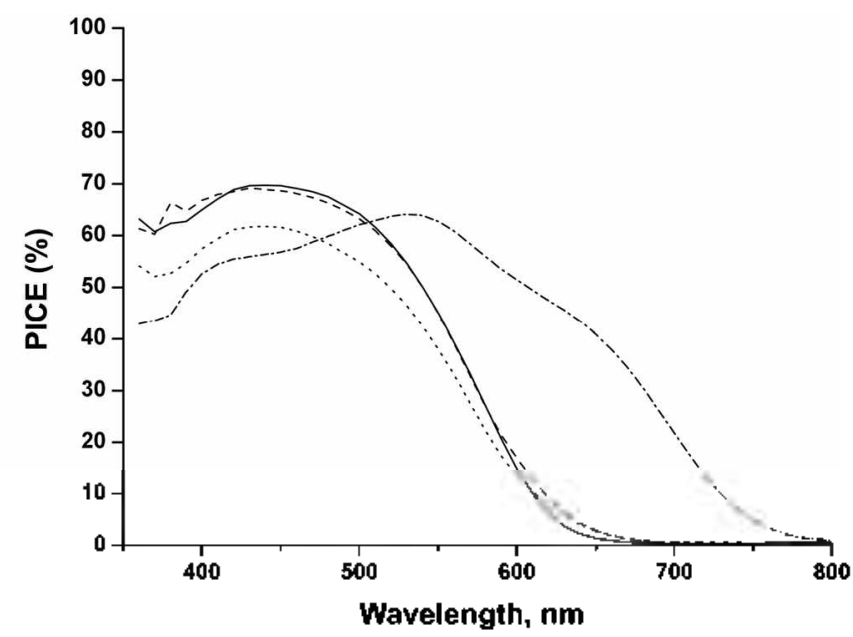

Figure 5. Spectra of monochromatic incident photon-to-current conversion cfficiencies (IPCEs) for DSSCs baseds on spectra of JK-34 (solid line), JK-35 (dashed line), JK-36 (dot line) and N3 (dashed dot line).

Figure 5 shows the incident monochromatic photon-tocurrent conversion efficiency (IPCE) for the DSSCs based on the three dyes. The IPCE data of JK-34 and JK-35 sensitizers in the peak maximum region are about $72 \%$ at $445 \mathrm{~nm}$. However, the maximum IPCE value $(60 \%)$ of JK$\mathbf{3 6}$ is lower than those of JK-34 and JK-35. A likely region for this may be attributed to the aggregation of the dye molecule on the $\mathrm{TiO}_{2}$ electrode. Although the DCA as coadsorbent to prevent the aggregation of dye on $\mathrm{TiO}_{2}$ film was used, their red shifts of maximum absorbance between in solution and on $\mathrm{TiO}_{2}$ film were observed with $13 \mathrm{~nm}$ for JK-34, $9 \mathrm{~nm}$ for JK-35 and $8 \mathrm{~nm}$ for JK-36.

In summary, we have designed and synthesized three organic dyes containing coumarin moiety bridged by thiophene units. The power conversion efficiency of the DSSCs based on the JK-34 $\sim \mathbf{J K}-36$ sensitizers reaches $4.34-4.54 \%$. The power conversion efficiency was shown to be sensitive to the structural modifications of bridging moieties. Contrary to our expectation, the JK-36 sensitizer with a high molar extinction coefficiency and red-shifted absorption band showed slightly lower conversion efficiency than $\mathbf{J K}$ 34 due probably to the aggregation and interaction between the dye and $\mathrm{TiO}_{2}$ film. Expanding the $\pi$-conjugation is necessary for the high molar extinction coefficiency, but the introduction of methine unit is worse in our case because the non-rigid conformation of bridging moiety occurs the energy loss via photoisomerization. Accordingly, the introduction of rigid $\pi$-conjugated expansion without a significant lowing of LUMO should be attained for the high efficiency of dye.

\section{Experimental Section}

General methods. All reactions were carried out under an argon atmosphere. Solvents were distilled from appropriate reagents. All reagents were purchased from Sigma-Aldrich. 7-Amino-3-bromo-4-methylcoumarin ${ }^{18}$ was synthesized using a modified procedure of previous reference. ' $\mathrm{H}$ and 
${ }^{13} \mathrm{C}$ NMR spectra were recorded on a Varian Mercury 300 spectrometer. Elemental analyses were performed with a Carlo Elba Instruments CHNS-O EA 1108 analyzer. Mass spectra were recorded on a JEOL JMS-SX102A instrument. The absorption and photoluminescence spectra were recorded on a Perkin-Elmer Lambda 2S UV-visible spectrometer and a Perkin LS fluorescence spectrometer, respectively.

Cyclovoltamogram: Cyclic voltammetry was carried out with a BAS $100 \mathrm{~B}$ (Bioanalytical Systems, Inc.). A threeelectrode system was used and consisted of a gold disk, working electrode, a platinum wire electrode. Redox potentials of dyes on $\mathrm{TiO}_{2}$ were measured in $\mathrm{CH}_{3} \mathrm{CN}$ with $0.1 \mathrm{M}$ $\left(n-\mathrm{C}_{4} \mathrm{H}_{9}\right)_{4} \mathrm{~N}-\mathrm{PF}_{6}$ a scan rate between $50 \mathrm{mVs}^{-1}$ (vs. $\left.\mathrm{Fc} / \mathrm{Fc}^{+}\right)$.

7-Amino-3-(5-(5,5-dimethyl-1,3-dioxan-2-yl)thiophen2-yl)-4-methylcoumarin (1): A stirred mixture of 7-amino3-bromo-4-methylcoumarin (2 g, $7.87 \mathrm{mmol}$ ), tributyl(5'(5,5-dimethyl-1,3-dioxan-2-yl)thiophen-2-yl)stannane (4.6 $\mathrm{g}, 9.44 \mathrm{mmol})$ and $\mathrm{Pd}\left(\mathrm{PPh}_{3}\right)_{4}(0.454 \mathrm{~g}, 0.39 \mathrm{mmol})$ in toluene $(50 \mathrm{~mL})$ was refluxed for $12 \mathrm{~h}$. After cooling the solution, $\mathrm{H}_{2} \mathrm{O}(10 \mathrm{~mL})$ and brine were added to the solution. The organic layer was separated and dried in $\mathrm{MgSO}_{4}$. The solvent was removed in vacuo. The pure product 1 was obtained by chromatographic work-up (eluent $\mathrm{EA}: \mathrm{Hx}=1: 3$, $\mathrm{R}_{f}=0.3$ ) as a green solid in $70 \%$ yield. Mp: $210^{\circ} \mathrm{C} .{ }^{1} \mathrm{H}$ NMR (DMSO-d $\left.)_{6}\right): \delta 7.50(\mathrm{~d}, J=8.4 \mathrm{~Hz}, 1 \mathrm{H}), 7.08(\mathrm{~d}, J=3.3 \mathrm{~Hz}$, $1 \mathrm{H}), 6.94(\mathrm{~d}, J=3.3 \mathrm{~Hz}, 1 \mathrm{H}), 6.60(\mathrm{~d}, J=8.4 \mathrm{~Hz}, 1 \mathrm{H}), 6.43$ (s, 1H), $6.22(\mathrm{br}, 2 \mathrm{H}), 5.69(\mathrm{~s}, 1 \mathrm{H}), 3.65(\mathrm{br}, 4 \mathrm{H}), 2.32$ (s, $3 \mathrm{H}), 1.16(\mathrm{~s}, 3 \mathrm{H}), 0.75(\mathrm{~s}, 3 \mathrm{H}) .{ }^{13} \mathrm{C}\left\{{ }^{1} \mathrm{H}\right\} \mathrm{NMR}\left(\mathrm{CDCl}_{3}\right): \delta$ $160.1,154.4,153.2,150.9,142.2,135.7,128.4,127.2$, $124.4,112.1,111.6,108.9,98.1,97.4,76.4,29.7,22.6,21.3$, 16.5. MS: $m / 2371\left[\mathrm{M}^{+}\right]$. Anal. Calc. for $\mathrm{C}_{20} \mathrm{H}_{21} \mathrm{NO}_{4} \mathrm{~S}: \mathrm{C}$, $64.67 ; \mathrm{H}, 5.70$. Found: C, 64.32; H, 5.45.

7-Amino-3-(5'-(5,5-dimethyl-1,3-dioxan-2-yl)-2,2'-bithiophen-5-yl)-4-methylcou-marin (2): Compound 2 was synthesized by a procedure similar to 1 except that tributyl(5'-(5,5-dimethyl-1,3-dioxan-2-yl)-2,2'-bithiophen-5yl)stannane $(5.37 \mathrm{~g}, 9.44 \mathrm{mmol})$ was used in place of tributyl(5'-(5,5-dimethyl-1,3-dioxan-2-yl)thiophen-2-yl)stannane. Yield: $76 \%$. Mp: $208^{\circ} \mathrm{C}$. 'H NMR (DMSO-d 6 ): $\delta 7.53$ (d, $J$ $=8.4 \mathrm{~Hz}, 1 \mathrm{H}), 7.29(\mathrm{~d}, J=3.9 \mathrm{~Hz}, 1 \mathrm{H}), 7.18(\mathrm{~d}, J=3.3 \mathrm{~Hz}$, $1 \mathrm{H}), 7.07(\mathrm{~d}, J=3.9 \mathrm{~Hz}, 1 \mathrm{H}), 7.06(\mathrm{~d}, J=3.3 \mathrm{~Hz}, 1 \mathrm{H}), 6.62$ $(\mathrm{d}, J=8.4 \mathrm{~Hz}, 1 \mathrm{H}), 6.44(\mathrm{~s}, 1 \mathrm{H}), 6.28(\mathrm{br}, 2 \mathrm{H}), 5.68(\mathrm{~s}, 1 \mathrm{H})$, $3.65(\mathrm{br}, 4 \mathrm{H}), 2.40(\mathrm{~s}, 3 \mathrm{H}), 1.17(\mathrm{~s}, 3 \mathrm{H}), 0.75(\mathrm{~s}, 3 \mathrm{H})$. ${ }^{13} \mathrm{C}_{\{}\{\mathrm{H}\} \mathrm{NMR}\left(\mathrm{CDCl}_{3}\right): \delta 160.1,154.3,153.3,150.8,140.2$, $137.0,136.3,135.8,135.1,130.5,127.3,126.3,123.3$, $123.0,111.7,109.0,98.0,97.1,76.3,29.8,22.6,21.3,16.7$. MS: $m / z 453\left[\mathrm{M}^{+}\right]$. Anal. Calc. for $\mathrm{C}_{24} \mathrm{H}_{23} \mathrm{NO}_{4} \mathrm{~S}_{2}: \mathrm{C}, 63.55$; H, 5.11. Found: C, 63.98; H, 4.98 .

7-(Bis(9,9-dimethylfluoren-2-yl)-3-(5-(5,5-dimethyl1,3-dioxan-2-yl)thiophen-2-yl)-4-methyl-coumarin (3): A stirred mixture of $\mathbf{1}(2 \mathrm{~g}, 5.38 \mathrm{mmol})$, 2-iodo-9,9-dimethylfluorene $(5.17 \mathrm{~g}, 16.15 \mathrm{mmol})$, powdered anhydrous potassium carbonate $(2.23 \mathrm{~g}, 16.15 \mathrm{mmol})$, copper bronze $(1.02 \mathrm{~g}, 16.15 \mathrm{mmol})$ and 18 -crown-6 $(0.43 \mathrm{~g}, 1.615 \mathrm{mmol})$ in 1,2-dichlorobenzene $(70 \mathrm{~mL})$ was refluxed for $48 \mathrm{~h}$. After cooling, the insoluble inorganic material was filtered off under suction and the dark brown filtrate was collected. The insoluble material was washed with dichloromethane $(3 \times 50$ $\mathrm{mL}$ ). The combined filtrate and organic phase ware washed with dilute aqueous ammonia and water and dried with magnesium sulfate. The solvent was removed under reduced pressure. The pure product 3 was obtained by silica gel chromatography (eluent $\mathrm{EA}: \mathrm{Hx}=1: 5, \mathrm{R}_{f}=0.4$ ) to afford 3 in $75 \%$ yield. Mp: $197{ }^{\circ} \mathrm{C} .{ }^{1} \mathrm{H}$ NMR $\left(\mathrm{CDCl}_{3}\right): \delta 7.67(\mathrm{t}, J=7.5$ $\mathrm{Hz}, 2 \mathrm{H}), 7.66(\mathrm{~d}, J=7.2 \mathrm{~Hz}, 2 \mathrm{H}), 7.47(\mathrm{~d}, J=9.0 \mathrm{~Hz}, 1 \mathrm{H})$, $7.41(\mathrm{~d}, J=7.5 \mathrm{~Hz}, 2 \mathrm{H}), 7.38(\mathrm{~d}, J=9.0 \mathrm{~Hz}, 2 \mathrm{H}), 7.32(\mathrm{t}, J=$ $7.2 \mathrm{~Hz}, 2 \mathrm{H}), 7.25(\mathrm{~s}, 2 \mathrm{H}), 7.17(\mathrm{~d}, J=8.7 \mathrm{~Hz}, 2 \mathrm{H}), 7.12(\mathrm{~d}, J$ $=3.9 \mathrm{~Hz}, 1 \mathrm{H}), 7.05(\mathrm{~d}, J=8.7 \mathrm{~Hz}, 1 \mathrm{H}), 7.00(\mathrm{~s}, 1 \mathrm{H}), 6.96(\mathrm{~d}$, $J=3.9 \mathrm{~Hz}, 1 \mathrm{H}), 5.65(\mathrm{~s}, 1 \mathrm{H}), 3.77(\mathrm{~d}, J=10.5 \mathrm{~Hz}, 2 \mathrm{H}), 3.64$ $(\mathrm{d}, J=10.5 \mathrm{~Hz}, 2 \mathrm{H}), 2.42(\mathrm{~s}, 3 \mathrm{H}), 1.43(\mathrm{~s}, 12 \mathrm{H}), 1.28(\mathrm{~s}$, $3 \mathrm{H}), 0.80(\mathrm{~s}, 3 \mathrm{H}) \cdot{ }^{13} \mathrm{C}\{\mathrm{l} \mathrm{H}\}$ NMR $\left(\mathrm{CDCl}_{3}\right): \delta 160.8,155.6$, $154.2,153.8,151.5,149.6,145.7,143.5,138.7,136.2$, $135.7,129.0,127.2,126.0,124.7,124.6,123.5,122.7$, $121.0,120.1,119.9,117.4,116.5,114.1,107.6,98.5,77.4$, 47.0, 31.7, 27.1, 23.1, 22.0, 17.0 MS: $m / 2755$ [M ]. Anal. Calc. for $\mathrm{C}_{50} \mathrm{H}_{4} \mathrm{NO}_{4} \mathrm{~S}: \mathrm{C}, 79.44 ; \mathrm{H}, 6.00$. Found: C, 78.97; $\mathrm{H}, 5.84$.

7-(Bis(9,9-dimethylfluoren-2-yl)-3-(5'-(5,5-dimethyl-1,3dioxan-2-yl)-2,2'-bithio-phen-5-yl)-4-methylcoumarin (4): Compound 4 was synthesized by a procedure to 3 except that compound $2(2.75 \mathrm{~g}, 8.59 \mathrm{mmol})$ was used in place of compound 1. Yield: $75 \%$. Mp: $186{ }^{\circ} \mathrm{C} .{ }^{1} \mathrm{H}$ NMR $\left(\mathrm{CDCl}_{3}\right): \delta$ $7.68(\mathrm{t}, J=8.4 \mathrm{~Hz}, 2 \mathrm{H}), 7.67(\mathrm{~d}, J=7.2 \mathrm{~Hz}, 2 \mathrm{H}), 7.51(\mathrm{~s}$, $2 \mathrm{H}), 7.49$ (d, $J=9.0 \mathrm{~Hz}, 1 \mathrm{H}), 7.41(\mathrm{~d}, J=7.1 \mathrm{~Hz}, 2 \mathrm{H}), 7.38$ $(\mathrm{d}, J=9.0 \mathrm{~Hz}, 2 \mathrm{H}), 7.32(\mathrm{t}, J=8.4 \mathrm{~Hz}, 2 \mathrm{H}), 7.18(\mathrm{~d}, J=7.2$ $\mathrm{Hz}, 2 \mathrm{H}), 7.13(\mathrm{~d}, J=7.1 \mathrm{~Hz}, 1 \mathrm{H}), 7.07(\mathrm{~d}, J=3.9 \mathrm{~Hz}, 1 \mathrm{H})$, $7.05-7.00(\mathrm{~m}, 3 \mathrm{H}), 6.99(\mathrm{~d}, J=3.9 \mathrm{~Hz}, 1 \mathrm{H}), 5.62(\mathrm{~s}, 1 \mathrm{H})$, $3.78(\mathrm{~d}, J=10.2 \mathrm{~Hz}, 2 \mathrm{H}), 3.64(\mathrm{~d}, J=10.2 \mathrm{~Hz}, 2 \mathrm{H}), 2.50(\mathrm{~s}$, $3 \mathrm{H}), 1.43(\mathrm{~s}, 12 \mathrm{H}), 1.29(\mathrm{~s}, 3 \mathrm{H}), 0.80(\mathrm{~s}, 3 \mathrm{H}) .{ }^{13} \mathrm{C}\left\{{ }^{1} \mathrm{H}\right\} \mathrm{NMR}$ $\left(\mathrm{CDCl}_{3}\right): \delta 160.9,155.6,154.1,153.8,151.5,149.3,145.7$, $140.4,139.1,138.7,137.6,136.2,134.5,130.4,127.2$, $127.1,126.0,125.9,124.8,123.4,122.7,122.2,121.1$, $120.2,119.9,117.4,116.7,114.1,107.5,98.3,76.5,47.1$, 30.3, 27.1, 23.1, 21.9, 17.1. MS: $m / 2838$ [M+]. Anal. Calc. for $\mathrm{C}_{54} \mathrm{H}_{47} \mathrm{NO}_{4} \mathrm{~S}_{2}: \mathrm{C}, 77.39 ; \mathrm{H}, 5.65$. Found: $\mathrm{C}, 76.87 ; \mathrm{H}$, 5.57 .

7-(Bis(9,9-dimethylfluoren-2-yl)-3-(5-formylthiophen2-yl)-4-methylcoumarin (5): THF (30 mL) and water (10 $\mathrm{mL}$ ) were added to a flask containing $3(1 \mathrm{~g}, 1.32 \mathrm{mmol})$. Then, TFA $(10 \mathrm{~mL})$ was added to the solution. The resulting reaction mixture was stirred for $2 \mathrm{~h}$ at room temperature. The solution was quenched with saturated aqueous sodium bicarbonate and extracted with dichloromethane. The combined dichloromethane phases were then washed with aqueous sodium bicarbonate and dried with $\mathrm{MgSO}_{4}$. The organic layer was removed in vacuo. The pure product 5 was obtained by silica gel chromatography (eluent $\mathrm{EA}: \mathrm{Hx}=1: 4$, $\mathrm{R}_{f}=0.3$ ) to afford 5 in $95 \%$ yield. Mp: $189^{\circ} \mathrm{C}$. ${ }^{1} \mathrm{H}$ NMR $\left(\mathrm{CDCl}_{3}\right): \delta 9.93(\mathrm{~s}, 1 \mathrm{H}), 7.77(\mathrm{~d}, J=3.9 \mathrm{~Hz}, 1 \mathrm{H}), 7.69(\mathrm{t}, J=$ $8.1 \mathrm{~Hz}, 2 \mathrm{H}), 7.68(\mathrm{~d}, J=8.2 \mathrm{~Hz}, 2 \mathrm{H}), 7.50(\mathrm{~d}, J=8.7 \mathrm{~Hz}$, $1 \mathrm{H}), 7.42$ (d, $J=8.2 \mathrm{~Hz}, 2 \mathrm{H}), 7.39(\mathrm{~d}, J=8.7 \mathrm{~Hz}, 2 \mathrm{H}), 7.33$ (t, $J=8.1 \mathrm{~Hz}, 2 \mathrm{H}), 7.26(\mathrm{~s}, 2 \mathrm{H}), 7.21(\mathrm{~d}, J=3.9 \mathrm{~Hz}, 1 \mathrm{H})$, 7.19 (d, $J=9.0 \mathrm{~Hz}, 2 \mathrm{H}), 7.06(\mathrm{~d}, J=9.0 \mathrm{~Hz}, 1 \mathrm{H}), 7.00$ (s, $1 \mathrm{H}), 2.46(\mathrm{~s}, 3 \mathrm{H}), 1.43(\mathrm{~s}, 12 \mathrm{H}) .{ }^{13} \mathrm{C}\left\{{ }^{1} \mathrm{H}\right\} \mathrm{NMR}\left(\mathrm{CDCl}_{3}\right): \delta$ 
$183.0,155.7,154.4,153.8,152.2,150.6,145.7,145.4$ $144.5,138.6,136.5,135.7,133.2,131.5,130.8,127.3$, $126.2,124.9,122.7,121.1,120.4,120.2,119.9,117.3,113.4$, 107.0, 47.1, 27.1, 17.1. MS: $m / z 669\left[\mathrm{M}^{+}\right]$. Anal. Calc. for $\mathrm{C}_{45} \mathrm{H}_{35} \mathrm{NO}_{3} \mathrm{~S}: \mathrm{C}, 80.69 ; \mathrm{H}, 5.27$. Found: C, 80.29; H, 5.16.

7-(Bis(9,9-dimethylfluoren-2-yl)-3-(5'-formyl-2,2'-bithiophen-5-yl)-4-methylcou-marin (6): Compound 6 was synthesized by a procedure similar to 5 except that compound 4 was used in place of compound 3. Yield: $95 \%$. Mp: $189^{\circ} \mathrm{C} . \mathrm{I}^{\mathrm{H}} \mathrm{NMR}\left(\mathrm{CDCl}_{3}\right): \delta 9.86(\mathrm{~s}, 1 \mathrm{H}), 7.70(\mathrm{~d}, J=3.9$ $\mathrm{Hz}, 1 \mathrm{H}), 7.68(\mathrm{t}, J=8.1 \mathrm{~Hz}, 2 \mathrm{H}), 7.67(\mathrm{~d}, J=7.6 \mathrm{~Hz}, 2 \mathrm{H})$, $7.50(\mathrm{~d}, J=9.0 \mathrm{~Hz}, 2 \mathrm{H}), 7.43-7.37(\mathrm{~m}, 3 \mathrm{H}), 7.35$ (d, $J=3.9$ $\mathrm{Hz}, 1 \mathrm{H}), 7.33(\mathrm{t}, J=8.1 \mathrm{~Hz}, 2 \mathrm{H}), 7.28(\mathrm{~d}, J=3.9 \mathrm{~Hz}, 1 \mathrm{H})$, $7.26(\mathrm{~s}, 2 \mathrm{H}), 7.18(\mathrm{~d}, J=7.6 \mathrm{~Hz}, 2 \mathrm{H}), 7.07$ (d, $J=9.0 \mathrm{~Hz}$, $1 \mathrm{H}), 7.05(\mathrm{~d}, J=3.9 \mathrm{~Hz}, 1 \mathrm{H}), 7.01(\mathrm{~s}, 1 \mathrm{H}), 2.57(\mathrm{~s}, 3 \mathrm{H}), 1.43$ (s, $\left.12 \mathrm{H}) .{ }^{13} \mathrm{C}_{\{1}^{1} \mathrm{H}\right\}$ NMR $\left(\mathrm{CDCl}_{3}\right): \delta 182.7,160.8,155.6$, $154.1,153.7,151.8,149.8,147.1,146.5,145.9,145.5$, $141.8,138.6,137.5,136.4,130.8,127.2,126.5,126.1$, $125.7,125.2,124.8,122.7,121.1,120.3,119.9,117.4,115.9$, $113.8,107.2,47.0,27.1,17.2$. MS: $m / z 751\left[\mathrm{M}^{+}\right]$. Anal. Calc. for $\mathrm{C}_{49} \mathrm{H}_{37} \mathrm{NO}_{3} \mathrm{~S}_{2}: \mathrm{C}, 78.27 ; \mathrm{H}, 4.96$. Found: $\mathrm{C}, 77.92$; $\mathrm{H}, 4.82$.

(E)-7-(Bis(9,9-dimethylfluoren-2-yl))-3-(5-(2-(5-(5,5dimethyl-1,3-dioxan-2-yl)thi-ophen-2-yl)vinyl)thiophen2-yl)-4-methylcoumarin (7): A mixture of $5(0.4 \mathrm{~g}, 0.59$ mmol), diethyl(5-(5,5-dimethyl-1,3-dioxan-2-yl)thiophen-2yl)methylphosphonate $(0.21 \mathrm{~g}, 0.59 \mathrm{mmol})$, and potassium tert-butoxide $(0.07 \mathrm{~g}, 0.59 \mathrm{mmol})$ was vacuum-dried and added THF $(30 \mathrm{~mL})$. The solution was refluxed for $6 \mathrm{~h}$. THF was removed under reduced pressure. The crude mixture was redissolved in dichloromethane, washed with water, and dried with $\mathrm{MgSO}_{4}$. The organic layer was removed in vacuo. The pure product 7 was obtained by silica gel chromatography (eluent EA:Hx $=1: 1, \mathrm{R}_{f}=0.4$ ) to afford 7 in $82 \%$ yield. Mp: $195^{\circ} \mathrm{C}$. ${ }^{1} \mathrm{H}$ NMR $\left(\mathrm{CDCl}_{3}\right): \delta 7.69(\mathrm{t}, J=7.2 \mathrm{~Hz}$, $2 \mathrm{H}$ ), 7.63 (d, $J=7.8 \mathrm{~Hz}, 2 \mathrm{H}), 7.49$ (d, $J=9.0 \mathrm{~Hz}, 1 \mathrm{H}), 7.42$ $(\mathrm{d}, J=7.8 \mathrm{~Hz}, 2 \mathrm{H}), 7.39(\mathrm{~d}, J=9.0 \mathrm{~Hz}, 2 \mathrm{H}), 7.33(\mathrm{t}, J=7.2$ $\mathrm{Hz}, 2 \mathrm{H}), 7.27$ (s, 2H), 7.18 (d, $J=9.0 \mathrm{~Hz}, 2 \mathrm{H}), 7.15$ (d, $J=$ $3.6 \mathrm{~Hz}, 1 \mathrm{H}), 7.07(\mathrm{~d}, J=9.0 \mathrm{~Hz}, 1 \mathrm{H}), 7.05-6.98(\mathrm{~m}, 5 \mathrm{H})$, $6.90(\mathrm{~d}, J=3.6 \mathrm{~Hz}, 1 \mathrm{H}), 5.60(\mathrm{~s}, 1 \mathrm{H}), 3.76(\mathrm{~d}, J=10.5 \mathrm{~Hz}$, $2 \mathrm{H}), 3.63$ (d, $J=10.5 \mathrm{~Hz}, 2 \mathrm{H}), 2.49$ (s, 3H), 1.44 (s, 12H), $1.29(\mathrm{~s}, 3 \mathrm{H}), 0.80(\mathrm{~s}, 3 \mathrm{H}) .{ }^{13} \mathrm{C}\left\{{ }^{\prime} \mathrm{H}\right\} \operatorname{NMR}\left(\mathrm{CDCl}_{3}\right): \delta 160.8$, $155.5,154.0,153.7,151.1,149.1,145.7,144.0,142.8$, $140.1,138.6,136.2,134.3,132.2,130.3,127.2,127.1$, $126.7,126.0,125.7,124.7,122.7,122.0,121.6,121.0$, $119.9,117.4,116.8,114.1,107.4,98.2,76.4,47.0,30.3$, 27.1, 23.0, 21.9, 17.1. MS: $m / z 864\left[\mathrm{M}^{+}\right]$. Anal. Calc. for $\mathrm{C}_{56} \mathrm{H}_{49} \mathrm{NO}_{4} \mathrm{~S}_{2}: \mathrm{C}, 77.84 ; \mathrm{H}, 5.72$. Found: $\mathrm{C}, 77.42 ; \mathrm{H}, 5.59$.

(E)-7-(Bis(9,9-dimethylfluoren-2-yl))-3-(5-(2-(5-formylthiophen-2-yl)vinyl)thiop-hen-2-yl)-4-methylcoumarin (8): Compound 8 was synthesized by a procedure similar to 5 . Yield: $95 \% . \mathrm{Mp}: 195{ }^{\circ} \mathrm{C} .{ }^{1} \mathrm{H}$ NMR $\left(\mathrm{CDCl}_{3}\right): \delta 9.83(\mathrm{~s}, 1 \mathrm{H})$, $7.69(\mathrm{~d}, J=7.2 \mathrm{~Hz}, 2 \mathrm{H}), 7.66(\mathrm{t}, J=8.1 \mathrm{~Hz}, 2 \mathrm{H}), 7.64(\mathrm{~d}, J=$ $3.9 \mathrm{~Hz}, 1 \mathrm{H}), 7.50(\mathrm{~d}, J=8.7 \mathrm{~Hz}, 1 \mathrm{H}), 7.42(\mathrm{~d}, J=7.2 \mathrm{~Hz}$, $2 \mathrm{H}), 7.39$ (d, $J=8.7 \mathrm{~Hz}, 2 \mathrm{H}), 7.32(\mathrm{t}, J=8.1 \mathrm{~Hz}, 2 \mathrm{H}), 7.27$ (d, $J=3.6 \mathrm{~Hz}, 1 \mathrm{H}), 7.26(\mathrm{~s}, 2 \mathrm{H}), 7.20(\mathrm{~d}, J=15.9 \mathrm{~Hz}, 1 \mathrm{H})$, 7.19 (d, $J=9.0 \mathrm{~Hz}, 2 \mathrm{H}), 7.13$ (d, $J=3.9 \mathrm{~Hz}, 1 \mathrm{H}), 7.10$ (d, $J$
$=3.6 \mathrm{~Hz}, 1 \mathrm{H}), 7.06(\mathrm{~d}, J=9.0 \mathrm{~Hz}, 1 \mathrm{H}), 7.01(\mathrm{~s}, 1 \mathrm{H}), 7.00(\mathrm{~d}$, $J=15.9 \mathrm{~Hz}, 1 \mathrm{H}), 2.50(\mathrm{~s}, 3 \mathrm{H}), 1.44(\mathrm{~s}, 12 \mathrm{H}) .{ }^{13} \mathrm{C}\left\{{ }^{\prime} \mathrm{H}\right\} \mathrm{NMR}$ $\left(\mathrm{CDCl}_{3}\right): \delta 182.6,160.7,155.6,153.7,152.1,151.7,151.4$, $149.4,145.5,142.8,141.5,138.6,137.4,136.3,130.6$, $127.8,127.2,126.7,126.0,125.8,125.6,124.8,122.7$, $121.1,120.6,120.2,119.9,117.4,116.4,113.9,113.8,107.3$ 47.0, 27.1, 17.1. MS: $m / z 777\left[\mathrm{M}^{+}\right]$. Anal. Calc. for $\mathrm{C}_{51} \mathrm{H}_{39} \mathrm{NO}_{3} \mathrm{~S}_{2}: \mathrm{C}, 78.73 ; \mathrm{H}, 5.05$. Found: $\mathrm{C}, 78.42 ; \mathrm{H}, 4.91$.

(E)-3-(5-(7-(Bis(9,9-dimethylfluoren-2-yl)amino)-4-methylcoumarin-3-yl)thioph-en-2-yl)-2-cyanoacrylic acid (JK-34): A mixture of $5(0.25 \mathrm{~g}, 0.37 \mathrm{mmol})$ and cyanoacetic acid $(0.06 \mathrm{~g}, 0.74 \mathrm{mmol})$ were vacuum-dried and added $\mathrm{MeCN}(60 \mathrm{~mL})$ and piperidine $(0.036 \mathrm{~mL}, 0.37$ mmol). The solution was refluxed for $8 \mathrm{~h}$. After cooling the solution, the organic layer was removed in vacto. The pure product JK-34 was obtained by silica gel chromatography (eluent $\mathrm{MC}: \mathrm{MeOH}=2: 1, \mathrm{R}_{f}=0.6$ ) to afford $\mathbf{J K}-34$ in $51 \%$ yield. Mp: $231{ }^{\circ} \mathrm{C}$. 'H NMR (DMSO-d $\left.\mathrm{d}_{6}\right): \delta 8.05$ (s, 1H), $7.87(\mathrm{~d}, J=8.4 \mathrm{~Hz}, 2 \mathrm{H}), 7.79(\mathrm{t}, J=7.2 \mathrm{~Hz}, 2 \mathrm{H}), 7.67(\mathrm{~d}, J=$ $3.9 \mathrm{~Hz}, 1 \mathrm{H}), 7.53(\mathrm{~d}, J=7.2 \mathrm{~Hz}, 2 \mathrm{H}), 7.46-7.28(\mathrm{~m}, 5 \mathrm{H})$, $7.22(\mathrm{~d}, J=8.4 \mathrm{~Hz}, 2 \mathrm{H}), 7.23(\mathrm{~s}, 2 \mathrm{H}), 6.95$ (d, $J=3.9 \mathrm{~Hz}$, $2 \mathrm{H}), 6.76(\mathrm{~s}, 1 \mathrm{H}), 2.44(\mathrm{~s}, 3 \mathrm{H}), 1.40(\mathrm{~s}, 12 \mathrm{H}) .{ }^{13} \mathrm{C}\left\{{ }^{1} \mathrm{H}\right\} \mathrm{NMR}$ (DMSO-d ${ }_{6}$ ): $\delta 162.8,159.3,155.2,153.4,151.3,150.6$, $144.9,141.7,140.5,140.1,138.3,137.9,135.8,130.6$, $129.5,128.7,128.1,127.1,124.9,123.9,123.1,122.7$, $121.4,120.4,119.9,115.0,113.1,105.7,46.5,26.6,17.1$. MS: $m / z 736\left[\mathrm{M}^{+}\right]$. Anal. Calc. for $\mathrm{C}_{48} \mathrm{H}_{36} \mathrm{~N}_{2} \mathrm{O}_{4} \mathrm{~S}: \mathrm{C}, 78.24$; H, 4.92. Found: C, 77.48; H, 4.81.

(E)-3-(5'-(7-(Bis(9,9-dimethylfluoren-2-yl)amino)-4-methylcoumarin-3-yl)-2,2'-bithiophen-5-yl)-2-cyanoacrylic acid (JK-35): Compound $\mathbf{J K}-35$ was synthesized by a procedure similar to JK-34. Yield: $58 \%$. Mp: $239^{\circ} \mathrm{C}$. ' $\mathrm{H}$ NMR $\left(\mathrm{DMSO}_{\mathrm{d}}\right): \delta 8.08(\mathrm{~s}, 1 \mathrm{H}), 7.86(\mathrm{~d}, J=7.8 \mathrm{~Hz}, 2 \mathrm{H}), 7.78(\mathrm{t}$, $J=8.1 \mathrm{~Hz}, 2 \mathrm{H}), 7.67(\mathrm{~d}, J=4.2 \mathrm{~Hz}, 1 \mathrm{H}), 7.53(\mathrm{~d}, J=7.8 \mathrm{~Hz}$, $2 \mathrm{H}), 7.49-7.43(\mathrm{~m}, 8 \mathrm{H}), 7.31(\mathrm{t}, J=8.1 \mathrm{~Hz}, 2 \mathrm{H}), 7.21(\mathrm{~s}$, $2 \mathrm{H}), 6.96(\mathrm{~d}, J=4.2 \mathrm{~Hz}, 1 \mathrm{H}), 6.79(\mathrm{~s}, 1 \mathrm{H}), 2.44(\mathrm{~s}, 3 \mathrm{H}), 1.40$ (s, $12 \mathrm{H}) .{ }^{13} \mathrm{C}\left\{{ }^{1} \mathrm{H}\right\}$ NMR (DMSO-d $\left.\mathrm{d}_{6}\right): \delta 162.5,159.2,155.2$, $154.4,151.3,150.3,145.9,141.2,140.5,140.1,138.3$, $137.2,136.8,130.6,129.5,128.7,128.1,127.1,125.3$, $124.9,123.9,123.1,122.9,122.7,122.1,121.4,120.8$, $120.4,119.9,115.0,114.1,109.7,46.5,26.6,17.3$. MS: $m / z$ 819 [M $\mathrm{M}^{+}$. Anal. Calc. for $\mathrm{C}_{52} \mathrm{H}_{38} \mathrm{~N}_{2} \mathrm{O}_{4} \mathrm{~S}_{2}: \mathrm{C}, 75.92 ; \mathrm{H}, 4.68$. Found: $\mathrm{C}, 75.47 ; \mathrm{H}, 4.59$.

(Z)-3-(5-(E)-2-(5-(7-(Bis(9,9-dimethylfluoren-2-yl)amino) -4-methylcoumarin-3-yl)thiophen-2-yl)vinyl)thiophen-2yl)-2-cyanoacrylic acid (JK-36): Compound JK-36 was synthesized by a procedure similar to $\mathbf{J K}-34$. Yield: $53 \%$. Mp: $221^{\circ} \mathrm{C} .{ }^{1} \mathrm{H}$ NMR (DMSO-d 6 ): $\delta 8.11(\mathrm{~s}, 1 \mathrm{H}), 7.83(\mathrm{t}, J$ $=8.1 \mathrm{~Hz}, 2 \mathrm{H}), 7.74(\mathrm{~d}, J=7.8 \mathrm{~Hz}, 2 \mathrm{H}), 7.63(\mathrm{~d}, J=3.6 \mathrm{~Hz}$, $1 \mathrm{H}), 7.52(\mathrm{~d}, J=7.2 \mathrm{~Hz}, 2 \mathrm{H}), 7.46-7.27(\mathrm{~m}, 10 \mathrm{H}), 7.24(\mathrm{~s}$, $1 \mathrm{H}), 7.20$ (d, $J=7.8 \mathrm{~Hz}, 2 \mathrm{H}), 7.13$ (d, $J=3.6 \mathrm{~Hz}, 1 \mathrm{H}), 6.94$ $(\mathrm{d}, J=8.1 \mathrm{~Hz}, 1 \mathrm{H}), 6.74(\mathrm{~s}, 1 \mathrm{H}), 2.45(\mathrm{~s}, 3 \mathrm{H}), 1.39(\mathrm{~s}, 12 \mathrm{H})$. $\left.{ }^{13} \mathrm{C}_{\{1}{ }^{1} \mathrm{H}\right\}$ NMR (DMSO-d 6 ): $\delta 163.5,159.7,156.2,153.4$, $152.3,150.3,146.9,141.7,140.8,140.1,138.3,137.2$, $135.8,132.6,129.5,128.7,128.1,126.1,125.6,124.8$, $124.1,123.4,123.1,122.9,122.5,122.1,121.4,120.8$, $120.4,119.9,118.4,117.0,113.1,110.7,46.5,26.6,17.1$. 
MS: $m / 2845\left[\mathrm{M}^{+}\right]$. Anal. Calc. for $\mathrm{C}_{54} \mathrm{H}_{40} \mathrm{~N}_{2} \mathrm{O}_{4} \mathrm{~S}_{2}: \mathrm{C}, 76.75$; H, 4.77. Found: C, 76.34; H, 4.57 .

Acknowledgements. This work was supported by a Korea Research Foundation Grant (KRF-2002-070-C00055) and BK-21 (2006).

\section{References}

1. Robertson, N. Angew, Chem. Int, Ed, 2006, 45, 2338.

2. (a) Wang, P.; Klein, C.; Humphry-Baker, R.; Zakeeruddin, S. M.; Grätzel, M. J. Am. Chem. Soc, 2005, 127, 808. (b) Chen, C.-Y,; Wu, S.-J.; Wu, C.-G; Chen, J.-G.; Ho, K.-C. Angew: Chent. Int. Ed. 2006, 45, 5822. (c) Jiang, K.-J.; Masaki, N.; Xia. J.; Noda, S.; Yanagida, S. Chem. Conmtm. 2006, 2460. (d) Jang, S.; Lee, C.; Choi, H.; Ko, J.; Lee, J.; Vittal, R.; Kim, K. Chem. Mater. 2006, 18,5604

3. (a) Nazeeruddin, M. K.; Kay, A.; Rodicio, I.; Humphry-Baker, R.; Müller, E.; Liska, P.; Vlachopoulos, N.; Grätzel, M. J. An. Chent. Soc. 1993, 115, 6382. (b) Nazeeruddin, M. K.; Péchy, P.; Renouard, T.; Zakeeruddin, S. M.; Humphry-Baker, R.; Comte, P.; Liska, P.; Cevey, L.; Costa, E.; Shklover, V.; Spiccia, L.; Deacon, G B.; Bignozzi, C. A.; Grätzel, M. J. Am. Chem. Soc. 2001, J23, 1613 .

4. Wang, P.; Zakeeruddin, S. M.; Moser, J. E.; Nazeeruddin, M. K.; Sekiguchi, T.; Grätzel, M. Nat. Mater. 2003, 2, 402.

5. (a) Hara, K.; Sato, T.; Katoh, R.; Furube, A.; Ohga, Y.; Shinpo, A.; Suga, S.; Sayama, K.; Sugihara, H.; Arakawa, H. J. Phys. Chem. $B$ 2003, 107, 597. (b) Hara, K.; Kurashige, M.; Dan-oh, Y.; Kasada, C.; Shinpo, A.; Suga, S.; Sayama, K.; Arakawa, H. New J. Chem. 2003, 27, 783. (c) Hara, K.; Sayama, K.; Ohga, Y.; Shinpo, A.; Suga, S.; Arakawa. H. Chent. Conmitm. 2001, 569.

6. (a) Horiuchi. T.; Miura. H.; Uchida. S. Chen. Contmitf. 2003. 3036. (b) Horiuchi, T.; Miura, H.; Sumioka, K.; Uchida, S. J. Am. Chem. Soc. 2004, 126, 12218. (c) Schmidt-Mende, L.; Bach, U.; Humphry-Baker, R.; Horiuchi, T.; Miura, H.; Ito, S.; Uchida, S.;
Gräızel, M. Atr, Mater, 2005, 17, 813. (d) Ito, S.; Zakeeruddin, S. M.; Humphry-Baker, R.; Liska, P.; Charvet, R.; Comte, P.; Nazeeruddin. M. K.; Péchy, P.; Takada, M.; Miura, H.; Uchida, S.; Grätzel, M. $A d$ : Mater. 2006, $/ 8,1202$.

7. (a) Hara, K.; Kurashige, M.; Ito, S.; Shinpo, A.; Suga, S.; Sayama, K.; Arakawa, H. Chem. Commm. 2003, 252. (b) Kitamura, T. Ikeda, M.; Shigaki, K.; Inoue, T.; Anderson, N. A.; Ai, X.; Lian, T.; Yanagida, S.; Chem. Mater. 2004, 16, 1806. (c) Hara, K.; Sato, T.; Katoh, R.; Furube, A.; Yoshihara, T.; Murai, M.; Kurashige, M.; Ito, S.; Shinpo, A.; Suga, S.; Arakawa, H. Ad, Funct, Mater: 2005, 15,246

8. (a) Sayama, K.; Tsukagoshi, S.; Hara, K.; Ohga, Y.; Shinpou, A.; Abe, Y.; Suga, S.; Arakawa, H. J. Phss. Chen. B 2002, 106, 1363. (b) Sayama, K.; Hara, K.; Mori, N.; Satsuki, M.; Suga, S.; Tsukagoshi, S.; Abe, Y.; Sugihara. H.; Arakawa, H. Chen. Commin. 2000, 1173 .

9. (a) Yao, Q.-H.; Shan, L.; Li, F.-Y;; Yin, D.-D.; Huang, C.-H. New J. Chem. 2003, 27, 1277. (b) Wang, Z.-S.; Li, F.-Y.; Huang, C.-H. Chem. Conmum. 2000, 2063.

10. Kim, S.; Lee, J. K.; Kang, S. O.; Ko, J.; Yum, J.-H.; Fantacci, S.; De Angelis, F.; Di Censo, D.; Nazeeruddin, Md. K.; Grätzel, M. J. Am. Chem. Soc. 2006, 128, 16701 .

11. Choi, H.; Lee, J. K.; Song, K. H.; Song, K.; Kang, S. O.; Ko, J. Tetrahedron $2007,63,1553$.

12. Jung, I.; Lee, J. K.; Song, K. H.; Song, K.; Kang, S. O.; Ko, J. J Org. Chem. 2007, 72, 3652 .

13. Choi, H.; Lee, J. K.; Song, K.; Kang, S. O.; Ko, J. Tetrahedron $2007,63,3115$.

14. Kim, D.; Lee, J. K.; Kang, \$. O.; Ko, J. Tetrahedron 2007, 63, 1913.

15. Raposo, M. M. M.; Fonseca, A. M. C.; Kirsch, G. Tetrahedron 2004, 60,407l.

16. Bushby, R. J.; McGill, D. R.; Ng. K. M.; Taylor, N. J. Mater. Chem. 1997, 7,2343.

17. Zhang, C.; Harper, A. W.; Dalton, L. R. Symh. Commun. 2001, 31, 1361 .

18. Schiedel, M.-S.; Briehn, C. A.; Bäuerle, P. Angew. Chem. Int. Ed. 2001, 40,4677. 